\title{
The Utilization of an Electronic Archival System to Support Archiving Services Offered by the University of Indonesia
}

\author{
$1^{\text {st }}$ Sofiana Rahmawati \\ Library and Information Science \\ Department, Faculty of Humanities, \\ Universitas Indonesia, \\ Depok, Indonesia \\ sofianar97@gmail.com
}

\author{
$2^{\text {nd }}$ Anon Mirmani* \\ Library and Information Science \\ Department, Faculty of Humanities, \\ Universitas Indonesia, \\ Depok, Indonesia \\ anon.mirmani@gmail.com
}

\begin{abstract}
The University of Indonesia's Archives Office provides direct archiving services but was not able to fulfill user needs because of the immense volume of its archives. Thus, it was difficult to serve user requirements for archived documents. Recent technological developments have facilitated the creation of the University of Indonesia's Archives Office's electronic archive system (SEKAR), which can assist archivists in managing archives more effectively and efficiently so users can retrieve archived material. This study aims is to discover the process of utilizing SEKAR to support archival services. This research project will benefit the Archive Office through the obtained knowledge of the functions of SEKAR that are already advantageous and will apprise officials about the features that still need improvement and that would encourage researchers to utilize SEKAR to obtain ameliorated archival services. This study employed the qualitative approach and data were collected from observations on the SEKAR as well as interviews conducted with some users and Archive and Service System Development Coordinators. The findings of this study reveal that SEKAR is effective in providing archival services to users and that it facilitates users through its search feature, digital files, and archive information request procedures.
\end{abstract}

Keywords-archives, electronic archive system, retrieval, archive services

\section{Introduction}

The role of information is pivotal in periods of development and growth. At such junctures, the need for information increases manifold. According to Moscove (1981), information is defined as reality that is presented in useful forms that can be used for the business of decisionmaking. An organization or institution makes the maximum effort to gather as much information as possible to support its business processes. This increase in information needs results from increasingly dynamic movements and management activities, which demand the availability and provision of fast and accurate information. Ab archive is an information source that is integral to management activities and that performs significant functions in an organization or institution. According to UU No. 43 of 2009, the archive is a record of activities or events in various forms and denotes the collection of media in accordance with the development of information and communication technology. Archives are initiated and accepted by state institutions, regional governments, educational institutions, companies, political organizations, community bodies, and individuals in the interests of the maintenance of life, nation, and state.
Given the importance of the archive as an information source, competent archive management is necessary for the production of beneficial service to users. Services may be evaluated as good if the process of retrieval of the archive is effectively operated so that the archived information required by the user can be obtained without the expense of an inordinate amount of time. The University of Indonesia's Archives Office was very concerned about the quality of services provided to its users. Conventional archiving services are most often used by users to fulfill their archived information needs. Over time, however, the archive volume increased to the extent that the required documents were difficult to find. An electronic file was then required to overcome the problem of retrieval. The Standards of Electronic Records Filing and Management in China defines electronic archives as documents created by digital devices, in digital formats, relying on digital devices such as computers for their reading and processing, and capable of being distributed through digital communication networks.

According to Australia's archives pertaining to electronic records for the management of books, an electronic archive denotes a document collection system created and maintained as proof of transactions, activities, and functions of institutions or individuals that are transferred and processed within and between computer systems. A similar definition is articulated by Wallace, who describes electronic archives as consisting of information sets recorded in the form of code that can be read and stored on several types of media so that it can be rediscovered, read, and used. Electronic archives can also be interpreted as all kinds of documents created using electronic media (e.g., computers) and stored in the form of digital files. Original archives that have been transferred or have been collected as images or scans and subsequently stored as digital files can also be labeled as electronic archives.

Archive retrieval may be facilitated by electronic archives and through archive location search features displayed in a system that displays the entire archive collection database. Therefore, a filing system is required to support archival services. According to Groonros (1990: 27) as cited by Ratminto and Atik [1], a service is an activity or series of invisible (inaccessible) actions that occur as a result of interactions between consumers and employees or other phenomena provided by service provider companies that are intended to solve problems faced by consumers or end-users. 
As times have progressed, the Indonesian Archives Office has initiated the use of technology to provide more effective and efficient services to users. Such use of technology was implemented at the University of Indonesia's Archives Office through the creation of an electronic archive system (SEKAR). SEKAR was developed to assist archivists in the management of their document repositories and to make it easier for end-users to process loans and retrieve archived documents. SEKAR encompasses discrete functions that support improved archive management. Effective archive management generates ameliorated services. The research question that formulates the problem addressed in this study is:

What is the process of using SEKAR to support the archiving services offered by the University of Indonesia?

\section{Method}

This study uses descriptive research methodology and employs the qualitative approach. As a research process and means of obtaining knowledge, the qualitative approach grounds itself in methodologies that investigate social phenomena and human problems. Qualitative research procedures produce descriptive data in the form of written and or spoken words or behavior ascertained through observation.

The data collection techniques used for this study include interviews and observations. Interviews were conducted with service and archive system development coordinators and with some service users. The observation entailed scrutiny of SEKAR, which is directly owned by the University of Indonesia Archive Office. The observation exercise appraised the menus and functions of each menu on the SEKAR website.

This study utilized domain analysis techniques to examine the obtained data. Domain analysis techniques may be utilized to attain a general but comprehensive description of research objects. These methods can afford a clear description of the utility of SEKAR in supporting archival services offered by the University of Indonesia's Archives Office. This study aims to determine the effectiveness of SEKAR by focusing on the rediscovery of archives and the process followed by the archival information request services.

\section{Results and Discussion}

The Archives Office is the archival institution of the University of Indonesia. It manages the document repositories of the university as well as archives produced by organizations and comprising information that is no longer directly used for daily administrative purposes. The University of Indonesia's Archives Office's archive management services conform to the standard operating guidelines (POB) for archives. The POB is intended to assist human resources at the University of Indonesia to appropriately execute archiving functions. According to the mission statement of the University of Indonesia's Archives Office, the usefulness of archives can be divided into the following functions:

\section{Usability for administration}

Institutions store documents for use as necessary to maintain organizational operations and reference services as per the requirements of the owners and staff members. Archives also fulfill the reporting requirements for administrative activities of institutions and can become the basis for decision-making by organizational leadership.

\section{Use in research}

Archives are stored and managed for the benefit of research and for external end-users with the main objective of preserving historical manuscripts. Reference service providers are prioritized for the satisfaction of the research needs of archival institutions that extend their services to users outside the parent institution.

\section{Public use}

Records are stored and managed because the government is responsible for the protection of the rights of its citizens. Public archives maintain individual records so they can serve discrete public needs and protect citizens.

The tertiary institution is also responsible for the organization and coordination of archives in education institutions. This duty to archive is also applicable to and is discharged by the Archive Office of the University of Indonesia, the archival institution of the University of Indonesia. The configuration of archives was stipulated by Law No.43 of 2009 with the aim to ensure the creation of archives of activities, to guarantee the availability of authentic and reliable records that could be used as valid evidence, and to guarantee reliable archive management and utilization of archives in accordance with the provisions of the legislation. The University of Indonesia's Archives Office discharges a crucial role in maintaining and managing depositories owned by the University of Indonesia so that the information they hold can be reused for the benefit of the institution. Therefore, the Office of Archives offers services that facilitate end-users who belong primarily to the University of Indonesia.

The University of Indonesia's SEKAR website can be accessed through the URL http://sekar.ui.ac.id/. Sugiharto and Wahyono (2005) define the electronic filing system as the use of electronic media to manage records based on computer use. SEKAR was created to assist the University of Indonesia's archivists to manage the institutional archives. SEKAR was developed by the Field of Service and Development of the Archives of the University of Indonesia and is the result of the archivist commitment of the University of Indonesia to the management of organizational information. SEKAR is also a tool that aids archivists in providing information services to the entire academic community of the University of Indonesia. Users of SEKAR may be divided into several types: anonymous, authenticated, repository operators, administrative repositories, and SEKAR's administrative officer, who is an archivist of the University of Indonesia's Archives Office. SEKAR automatically $\operatorname{logs}$ a user out if there is no activity for 30 minutes.

SEKAR was tethered to a website to enable information seekers to quickly find archived documents stored by the University of Indonesia's Archives Office. A website is an Internet platform that displays information in the form of text, images, audio, and interactive videos. Websites offer the advantage of linking one document with another (hypertext) and can be accessed through a browser 
(Yuhefizar (1998). Web-based applications offer the advantage of being and are easily and quickly accessed through a browser and a device with an Internet connection. Thus, the user community finds it simple to browse through data or information using a laptop, tablet, smartphone, or another Internet-capable device such as a home desktop computer. Of course, the application must be installed on every device that could be used to access the archives.

Christopher D. Manning (2008: 3) elucidated the reasons for using computer-based systems as follows:

a) To instantly search through large collections of documents

b) To allow more flexible matching operations

c) To enable the retrieval of information in accordance with the user's information needs

Since it is website based, SEKAR can be accessed anywhere and at any time, 24 hours a day. Searched files can also be immediately located, certainly faster than manual means. One of SEKAR's principal benefits concerns the multi-repository archival system used by the University of Indonesia. These numerous repositories are expected to form cells of an archival repertoire, particularly for use by the University of Indonesia but also for the benefit of the general domain of Indonesian education. Ladiawati (2007: 79) asserts that electronic archival systems can also ensure the security, durability, and duplication of archives. When electronic archives are supported with all the necessary equipment, software, and electronic media, they can generate effective and efficient results by enhancing all archival activities. Besides being practical in their use, they can also ensure the security and monitor the physical condition of the maintained archives.

McCall (1977) posits several factors that influence the quality of a system. The product operation or the technical properties of a system are dependent on:

a) Accuracy or the extent to which a system can meet the specifications and mission objectives of its users. According to the end-users, SEKAR is not yet optimal in its features, which require more diversity. Also, there are not enough electronic archives to properly fulfill all user needs.

b) Reliability or the extent to which a system can be expected to execute its functions with the necessary precision. Users state that SEKAR is satisfactorily trustworthy because problems or errors on the website are very rare. There is only a single feature or menu named pencipta arsip that is not accessible.

c) Efficiency is assessed on the basis of the quantum of computational resources and codes needed by the program to implement its functions properly and correctly. The collected data suggest that SEKAR's efficiency factor is superior. The processing speed to access the website is extremely fast and users have never experienced a server down situation.

d) Integrity refers to a system's capabilities with regard to software security, particularly in terms of the prevention of unauthorized access. A system can be said to have integrity if it can control access and identify entitled and accountable users according to rights accorded to them.
SEKAR is judged to be excellent in this feature because of the website's fairly strict security protocols. Only users who $\log$ in to SEKAR can access archived information or download digital files owned by the University of Indonesia's Archives Office. Login data includes email and passwords issued only to the academic community of the University of Indonesia.

e) Usability pertains to the assessment of its operational quality for the end-user. It is tested through the effort required by the user to study, operate, provide inputs, and interpret outputs. The interviewed users rated SEKAR as good in this parameter because the website's operation is simple for all types of users. In addition, the SEKAR website includes a help feature to support visitors in the event of any difficulties.

In addition, SEKAR incorporates certain aspects that specifically support the services of the University of Indonesia's Archives Office:

\section{Search}

This feature is used to explore archived documents required by users. The efficient search feature on SEKAR can save users time as users can instantly discover the location of the desired records without having to directly visit the repositories of the University of Indonesia's Archive Office. This feature simplifies the process of archive retrieval. Information retrieval is an activity that is systematically executed to discover the location of the desired document sources, the information they contain, whether a record must be manually searched and whether the material can be obtained using information technology (Lasa, 2009: 337).

Digital format archives can make the retrieval of archived information effortless through their location search features. These search options are generally presented in a system that displays the entire archive collection database. According to Lasa (2009: 38), databases should be compiled for the following reasons:

a) To manage data to make it easily discoverable

b) To integrate the information managed at each work or archival unit

c) To present complete and comprehensive information

d) To act as a retrieval tool

e) To record information offered by an organization or institution

The search feature is equipped with specific options to make it easier for users to know about the archive they require. This specific search is divided into five categories: archive information, archive creator, organizational unit, classification, and digital files. Archive information is searched based on the topic or contents of the archive. The creator of the archive is searched based on the person or institution that generated the archived material. Organizational units are sought based on archival units such as faculties or PAU work units that own or create the archived content. Material may also be searched through classification codes in accordance with applicable guidelines. 
The searchable digital files are based on physical archives digitized by the University of Indonesia's Archives Office.

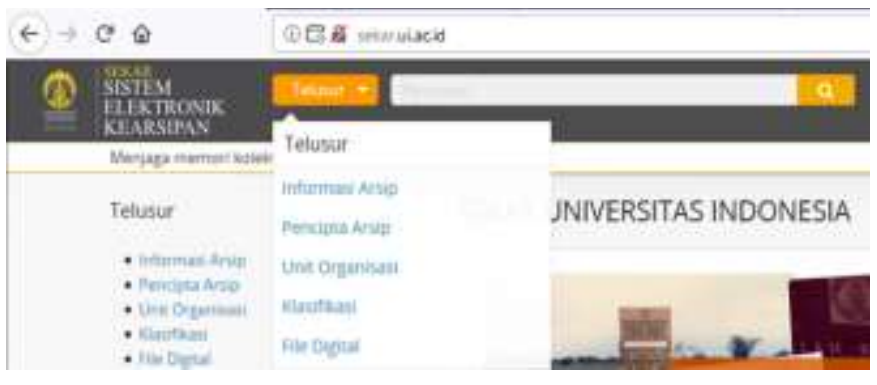

Fig. 3.1 Display Search Features (source: sekar.ui.ac.id)

Lancaster and Ken are cited in Mahdiah's study (2011: 24) to enumerate the functions of the information or archive retrieval system. These purposes include:

a) To identify sources of information that are relevant to the interests of the targeted user community

b) To analyze the contents of information sources/documents

c) To present the contents of a document in a certain way that allows it to answer user queries

d) To express user queries in a certain way that allows matching them with the source of information/documents contained in the database

e) To respond to search statements with information stored in the database

f) To rediscover relevant information

g) To improve systemic performance based on the feedback provided by users

SEKAR was developed by taking into account several of the above functions so that the system's retrieval functions could be appropriately accessed by users. The University of Indonesia's Archives Office has already digitized 10\% of its archives, mostly permanent and vital documents and material such as maps, laws, and supervisory information, etc. Files are digitalized in the form of images, text, or videos as may be necessary. However, the electronic archives of the University of Indonesia Archives are still inadequate because of the paucity of supporting equipment required to digitize archives. Digitization necessitates designated space equipped with large tables, cameras, and lighting appropriate for photography and filming. The depositories owned by the University of Indonesia's Archives Office are quite old and the use of scanners cannot be applied to a lot of the stored documents.

The electronic archives can be accessed and digitalized forms of the researched material can be downloaded through SEKAR. In addition, SEKAR can also instantly help users find the location where the physical document or material is stored if it is not yet digitalized so users can access their desired material at the appropriate location. However, SEKAR is fairly strict about access. New users can download electronic archives after logging in with their registered email address and password. If the user does not possess an email identification or password to $\log$ in to the SEKAR website, a form must first be filled in the archive information request service menu to download archived material from the SEKAR website.

\section{Archive Information Request Service}

This service provides archival access to users who cannot be granted email identification and passwords to log in to the SEKAR website. The access protocol established by the University of Indonesia's Archives Office is indeed quite stringent because the university's depositories are of great importance. Users who want to borrow archived documents or download material must meet the requirements set by the Office of Archives. Primarily, they must complete the archive information request form. This form requires the prospective user to fill in information about the user's identity: name, email address, telephone number, identity number (KTP/NIP/NPM), user status (staff education/student/alumni/general), type of service required (request for information/loan archive), subject of interest of the requested archive, as well as the purpose of requesting the archived information. Before submitting the form, prospective users must also accurately enter the code contained in an image as an extra layer of security.

The University of Indonesia's archival office fundamentally extends two types of services. The first service type pertains to users who desire archival information such as the location of archives and digital files available on SEKAR. The second bouquet of services concerns users who want to borrow archived material in physical form. Users who complete the archive information request service form must wait several days. If a user wants to borrow a physical file, an archivist checks the availability of the archived material by inspecting the archive list. Once the material is located, the archivist assesses the access requirements and security levels of the concerned archive. Physical or digital requests for archived material are first inspected by an archivist to confirm the identity of the user and to ascertain the purpose of borrowing or requesting files. Next, the archivist determines the nature of the archived material and ascertains whether or not the requested material is available or accessible to the user. Information system security involves technical security controls and also requires administrative, procedural, and managerial controls (Papagiannakis, Pijl, \& Visser, 2011). How employees, managers, or IT personnel use organizational information systems influences the continuity and availability of a company's information assets.

Despite its tight controls, the archive information request service really helps users and the system makes it easier for authorized users to borrow or request archived information. If this service cannot be located on the SEKAR website, users must directly visit the Archives Office to complete the archive information request formalities and must return to the Archive Office to borrow the archived material if it sanctioned by the archivist. Those already authorized on the SEKAR website need only visit the University of Indonesia's Archives Office once to pick up their requested material.

Archived material requested by users can only be viewed and read in reading rooms allocated by the Archives Office. In addition, users can also photograph some portions of the archived material required for their sanctioned purposes. However, if the archived material requested by the user does not exist, the user can write a recommendation letter 
regarding the non-availability and submit it to the Archives Office service department. The Archives Office will then attempt to procure the requested material for the user.

\section{Conclusion}

The University of Indonesia's Archives Office has implemented an electronic filing system called SEKAR to support archival activities. SEKAR operates in accordance with the university's objective of improving its extensive archival services. The SEKAR application also helps users access accurate and updated information on archived material stored and owned by the University of Indonesia's Archives Office, which manages the database through several classifications of archive fields to make the information search easier for users. The SEKAR application can also aid the preservation of the archives. Once digitized, vital past information and scientific and technological knowledge can be preserved and can easily be accessed in the future without fear of corruption or loss.

The search features on SEKAR's website can support the physical and offline services offered by the University of Indonesia's Archives Office. Users can more easily locate the required archival information. Besides, SEKAR's online information request service is intended to facilitate users in their quest to borrow or request archival information. SEKAR thus makes the archive service process more effective and efficient. Its website-based services simplify the fulfillment of user demands and archival services can be availed by authorized users anywhere and at any time.

However, some aspects of SEKAR still need restructuring or must be upgraded to make the system even better. Also, more of the discrete archived material in the university's repositories must be digitized to augment the quantum of digital files that already store electronic records of the University of Indonesia's Archives Office. This digitization of physical material can facilitate users, who can download the archives they need; it can also protect the invaluable records from being lost unforeseen catastrophes and preserve the knowledge contained within them. In addition, SEKAR's features lack adequate diversity its lack of interface with the service personnel of the Archives Office makes it difficult for users to interact directly with archivists. For the moment, SEKAR only lists telephone numbers that can be contacted if the user has further queries.

\section{Acknowledgments}

This research project was accomplished with the help of the archivists of the University of Indonesia's Archives Office. I am especially grateful to the archive and service system development coordinators who provided the data for this study. The paper was also perfected through suggestions and comments received from my lecturer, Mrs. Anon Mirmani.

\section{References}

[1] Atik, S. W., \& Ratminto. (2005). Manajemen Pelayanan. Yogyakarta: Pustaka Pelajar.

[2] Moscove, Steven A. (1981). Accounting Information System: Concepts and Practice For Effective Decision Making. Wiley.

[3] Sugiarto, Agus \& Wahyono, Teguh. (2005). Manajemen Kearsipan Modern. Yogyakarta: Gava Media.

[4] Yuhefizar. (2008). 10 Jam Menguasai Internet: Teknologi Dan Aplikasinya. Jakarta: PT Elex Media Komputindo.

[5] Manning, Christopher D. (2008). Introduction Information Retrieval. California: Stanford University.

[6] Ladiawati, Dewi. (2007). Pelestarian Arsip Menyelamatkan Warisan Budaya Bangsa. Jurnal Kearsipan ANRI, Vol.2, 1-16. Jakarta: Arsip Nasional Republik Indonesia.

[7] McCall, J.A., Richards, P.K. \& Walters, G.F. (1977). Factors in Software Quality, Vol.I-111. Italy: Rome Air Development Centre.

[8] HS, Lasa. (2009). Kamus Kepustakawanan Indonesia. Yogyakarta: Pustaka Book Publisher.

[9] Mahdiah. (2011). Evaluasi Kinerja Slims Sebagai Sarana Temu Kembali Informasi Di Perpustakaan DPR RI. Jakarta: Ilmu Perpustakaan Dan Informasi UIN Syarif Hidayatullah Jakarta.

[10] Papagiannakis, K., Pijil, G. V., \& Visser, A, D. (2011). An Overview of The Current Level of Security Awereness In Greek Companies. Erasmus University of Rottersam. 